\title{
Investing in climate solutions? An exploration of the discursive power and materiality of fossil fuel divestment campaigns in Scotland
}

\author{
Ella Muncie ${ }^{1}$ (1) \\ Accepted: 11 December 2020 / Published online: 19 December 2020 \\ (C) The Author(s) 2020
}

\begin{abstract}
Divestment is a climate change initiative that aims to persuade institutions, businesses, and governments to remove their financial investments from fossil fuel industries and instead invest in zero-carbon climate solutions. It has, however, also been conceived as an ongoing gateway tactic to curb long-term climate change and simultaneously secure social and environmental justice. Divestment has attracted global attention and is currently employed by numerous universities, religious institutions, art galleries, museums, and national and local governments, in various countries, including Scotland. However academic analysis of the movement remains underdeveloped. This article addresses such absence by giving a voice to the motives, tactics, and rationales as expressed by campaigners themselves. It identifies the collective action frames constructed by Scottish fossil fuel divestment campaigns in order to facilitate mobilisation and alignment with other climate change movements. A key premise of this article is to also explore the power of such frames to motivate action and to assess the extent to which divestment campaign groups can impact government discourse and policy. As such the article concludes by considering whether and how far divestment frames and discourses may have come to inform the climate change policy of the devolved Scottish Government.
\end{abstract}

Keywords Climate change $\cdot$ Climate emergency $\cdot$ Discourse $\cdot$ Divestment $\cdot$ Fossil fuels $\cdot$ Framing $\cdot$ Scotland

\section{Introduction}

I'm very clear to myself, that the tactic is divestment, the campaign is stopping climate change and the end goal is social justice. And that not the way we campaign or the way we use tactics should undermine that end goal (Friends of the Earth Scotland).

This article explores continuities and divergences in the ways the 'wicked issue' of climate change has been formulated and addressed by environmental social movements and by governmental practice and policy. It focuses on the 2019 Divest Scotland campaign, coordinated by Friends of the Earth Scotland, which was specifically designed to speak directly to members of the Scottish Parliament (MSPs). A key aim was to seek

Ella Muncie

em471@1eicester.ac.uk

1 School of Media, Communication and Sociology, University of Leicester, Leicester LE1 7RH, UK a commitment that MSP pension funds and the forthcoming Scottish National Investment Bank would desist from investing in fossil fuel industries. In Scotland, a unique web of divestment movements has recently emerged targeting educational, religious, and local and national political institutions. As such, Divest Scotland calls upon these other institutions to also invest in zerocarbon climate solutions. The ultimate goal of divestment, however, as revealed in the activist quote above, is ultimately much broader. Divestment can also be conceived as an initial tactic in an ongoing-and longterm-campaign to reverse climate change and simultaneously secure social and environmental justice. To explore this in some depth, interviews with campaigners reveal three defining collective action frames of divestment campaigns in Edinburgh and Glasgow: (1) Financial Risk and Economics, (2) Climate Justice, Morality and Ethics, and (3) 'Climate Emergency' and Urgent Action. This article considers the power such frames may have to motivate action and assesses the extent to which Divest Scotland in particular, and the Scottish divestment movement in general, has impacted government discourse and policy. 


\section{Fossil fuel divestment}

Fossil fuel divestment campaigns originate from the early 2010s. They have taken inspiration from the South African divestment movement which succeeded in bringing down the Apartheid regime in the 1980s. That movement involved 22 countries and 90 cities removing financial support from multinationals that were doing business in South Africa. Bratman et al. (2016) argue that fossil fuel divestment campaigns aim to achieve the same effect on the carbon-polluting industries. Both are designed to expose exploitative practices, focus attention on the actors that profit from the status quo, and force a moral revaluation of the structures, and exercise, of political and economic power.

The fossil fuel divestment movement was kick started in the USA by Bill McKibben, a co-founder of the climate advocacy group 350.org. McKibben argues that fossil fuel industries need to be recognised as the public's 'number one enemy'. He famously stated: 'money is the oxygen on which the fire of global warming burns' and 'if it's wrong to wreck the climate, it's wrong to profit from that wreckage' (McKibben 2012). The movement initially focussed on targeting US university endowment funds. In 2012, Unity College (America's Environmental College) became the first institution to divest from fossil fuels. It aimed to reduce its fossil fuel investments from 3\% to less than $1 \%$. Despite such modest ambitions, it set a precedent for other universities worldwide. Divestment has since been implemented to various degrees in over half of the UK's higher education sector (The Guardian 2 October 2020). As funding from central government has been consistently removed, since the 1980s such institutions sought to close the funding gap by adopting free market neoliberal business models, politics, and economics. This included investing in fossil fuel industries. Universities have been a primary target for divestment, with students often being the driving force behind social movement mobilisation. Indeed, most literature to date has focussed on the pros and cons of fossil fuel divestment in US higher education (Grady-Benson 2014; Bratman et al. 2016; Healy and Debski 2017). Rationales for divestment include upholding the university's reputation and reducing financial risk, while arguments against contend that fossil-free investments underperform, divestment has no material effects on climate change, and universities should not get involved in politics (Cleveland and Reibstein 2015). Nevertheless, GradyBenson (2014) and Curnow and Gross (2016) highlight how divestment has mobilised and radicalised a new generation of activists (students) to fight climate crises, challenge dominant paradigms, and significantly influence public discourse. By December 2018, over 150 campuses worldwide had committed to divest. In 2014, the University of Glasgow in Scotland was the first university in Europe to begin to phase out investment in fossil fuel companies.
By 2018, it has been claimed that over 1000 divestments had been achieved worldwide and over $£ 6.4$ trillion worth of investments had been removed (McKibben 2018). As a result, the divestment movement is believed to be one of the most effective anti-corporate campaigns to date: 'no tactic in the climate wars has resonated more powerfully' (Klein 2014, p. 354).

Importantly, most commentators acknowledge that the main aim of divestment is not just to weaken fossil fuel industries financially, but also to weaken them politically (Rowe et al. 2016). It aims to shame and stigmatise. Similarly, Gunningham (2017, p. 310) emphasises the key role campaigns can play in simultaneously 'involving a demand (divest), a promised reward if the target meets the demand (maintaining reputation, avoiding stranded assets as fossil fuel stocks rapidly devalue), and a threat of harm if the target rejects the demand (shaming and stigmatization)'. Divestment may not immediately weaken the financial standing of fossil fuel companies, but it does bring questions of morality to the fore of the climate change debate. Divestment is commonly viewed as a gateway campaign. While it withdraws mass consent from the fossil fuel industry, it also plants the seeds for recognition of the inequities of neoliberal and unrestrained market expansion. It has allowed a broad and diverse range of participants to be united under a common cause, in effect transforming ordinary citizens into climate 'activists' (Rowe et al. 2016; Bratman et al. 2016; Curnow and Gross 2016; Healy and Bary 2017). Above all, 'given the very slow pace of responses to climate change so far, divestment voices add a much-needed urgency to the narratives of climate politics' (Mangat et al. 2018, p. 202).

\section{Researching divestment discourse in Scotland}

Scotland has long claimed to be a world leader in progressive climate change policies (Scottish Government 2020). To test this proposition, I initially contacted Friends of the Earth Scotland to explore their Divest Scotland campaign. This then led me to research aligned campaigns, such as those organised by Divest Lothian, Fossil Free Glasgow, The Church of Scotland, and People and Planet Edinburgh. Interviews were arranged with fifteen key members/activists across all such campaigns during May/June 2019. Each interview typically lasted between 60 and 90 minutes.

The initial focus of this research was the Divest Scotland campaign, coordinated by Friends of the Earth Scotland. It was established in 2019 and was specifically designed to speak directly to members of the Scottish Parliament (MSPs). The campaign aimed to ensure that investments in MSP pension funds and the forthcoming Scottish National Investment Bank were removed from fossil fuel industries and that the Scottish Parliament was committed to building a 
zero-carbon future. As of September 2019, 20 MSPs (out of 129) had signed a pledge to divest.

However, due to the infancy of this campaign, interrelated divestment campaigns (listed below) were also researched to place Divest Scotland in its broader context:

- Divest Lothian campaigns for the Lothian Council Pension Fund to divest from fossil fuel companies and instead invest in sustainable projects. The Lothian Pension Fund invests $£ 153$ million in fossil fuel companies, such as Shell and BP. As of June 2018, 13 councillors had signed a pledge to divest the fund but despite this divestment has yet to be achieved.

- Fossil Free Glasgow campaigns for Strathclyde Pension Funds to divest. This has been a long running campaign with mixed results. For example, Glasgow City Council declared a climate emergency in 2019, yet retains over $£ 700$ million invested in fossil fuel companies.

- People and Planet Edinburgh have run a long campaign to persuade the University of Edinburgh to divest. In 2015, following a 10-day occupation, the University divested from coal and tar sands. In 2018, the University announced it would be removing its entire investment portfolio from all fossil fuel industries, over a 3-year period. This made it the largest full divestment commitment of any UK university at the time.

- In May 2018, The Church of Scotland rejected divestment by 300 votes to 135 . In May 2019, there was another attempt to get the Investors Trust to divest, but this was defeated by 303 votes to 263 . While the Church recognises and affirms the Scottish Government's declaration of a climate emergency, it continues to hold shares in BP, Shell, and Total.

While the primary focus of this research is on the Divest Scotland campaign and its potential to influence the Scottish government's position and policy on climate change, it remained important to explore the discursive work employed by other divestment campaigns in Edinburgh and Glasgow. All divestment campaigns in Scotland are centrally supportedby Friends of the Earth Scotland. Data from the interviews allowed me to identify resonant frames that persisted over time and place and across the various campaigns. In this way, a more comprehensive understanding was gained of how divestment, as a concept, is generated, diffused, and negotiated through collective action frames. The latter as defined by Benford and Snow (2000, p. 614) are 'action-oriented sets of beliefs and meanings that inspire and legitimate the activities and campaigns of a social movement'. Similar to the method employed by Mangat et al. (2018, pp. 191-2), an initial inductive analysis of the interview data was fine-tuned to eventually identify three 'broad narratives' and legitimating frames of the divestment movement which emerged as particularly pertinent to a Scottish context. These were the following: financial risk and economics (highlighting the financial risk of fossil fuel investments); climate justice, morality, and ethics (suggesting greater consideration should be given to the ethics of climate change); and climate emergency and urgent action (highlighting the urgency with which climate change should be addressed). As is common in framing research, the goal was to reveal how the communicator or 'frame advocate' of a message uses discursive elements in order to frame a certain topic/ issue in a particular manner. As a methodology, such an approach eventually allows the researcher to identify the structural and rhetorical features of 'texts' (such as official documents and interview data) which are designed to promote particular messages and collective actions. Typical accusations of researcher subjectivity embedded in such an approach are addressed through a systematic identification of recurrent themes, vocabulary, and language that denote the frame (Pan and Kosicki 1993).

The three frames were subsequently applied to an analysis of official climate change policy documents produced by the Scottish government between 2009 and 2019. A key concern was to examine how policy documents produced certain environmental meanings and emphasised particular environmental knowledge. As a result, an initial assessment of the congruence of campaigner (as derived from interview data) and governmental (as derived from documentary analysis) 'action frames' was made possible.

\section{The logic of divestment: collective action frames}

\section{Financial risk and economics}

Campaigners understand that fossil fuel investments can be lucrative for institutions and companies, but reconstruct this narrative to highlight the equal, if not greater, financial stability of fossil-free investments. For example, a campaigner from Divest Lothian stated, 'One of our counter arguments would be we have evidence that carbon free funds can perform well if not even better. So if you invest in renewables it doesn't mean you're going to lose money'.

Financial framings are prevalent in campaigns which underline the financial risk of investing in fossil fuel industries. The terms 'carbon bubble', 'stranded assets', and 'unburnable carbon' were used throughout the interviews. Such terms draw attention to how, as countries begin to tackle climate change by transitioning towards renewables, significant fossil fuel reserves will remain unexploited. However, the fuels that will remain in the ground already play a significant part in the economy aboveground. They are used to calculate share prices and companies are able to borrow money against them 
(McKibben 2012, n.p.). They are the primary asset of fossil fuel companies. Many interviewees made comparisons to the 2008 financial crisis, as akin to the housing bubble, the 'carbon bubble' is expected to burst, leaving many investors with worthless assets (Moore 2011). This was concisely expressed by a campaigner from Fossil Free Glasgow, 'The only way they're making money is through speculating in Wall Street, so what's happening is that this huge carbon bubble is being inflated and if that carbon bubble bursts there'll be huge amounts of investments and stranded assets'.... 'My money, my pension, is still being invested in companies whose value is based upon the oil, the coal, the gas that's still in the ground, which governments are basically saying I'm not going to take out the ground in the future. So the value of those investments is declining'.

Campaigners said they were most likely to focus on financial arguments when talking to MSPs or pension fund managers. They were aware that when targeting people in professional positions or trying to influence government policy, it was beneficial to bring a financial angle to the conversation. Others believed that focusing on economic arguments contradicted and undermined the overarching end goal of divestment. For instance, a representative from Friends of the Earth Scotland argued, 'I am very reluctant to use financial framings because if we do that we implicitly say two other things as well. One, that the profit motive is the most important thing to worry about, not moral concerns or teaching society whatever. And two, that bankers are clever and interesting people and it's good to listen to them, which evidence suggests is not the case following the 2008 financial crisis'. Campaigners were aware that by making finance the core narrative, governments, and institutions can continue to justify their climate actions based on economics, while ignoring moral and climate justice implications. This concern was further raised by People and Planet Edinburgh, 'We considered that economic frame, that companies are sitting on top of tens of thousands of stranded assets and that the market is going to collapse. But we tend to keep away from that because we're trying to persuade the government and those high up in the fossil fuel industry that it's not just about profits and turnover'.

\section{Climate justice, morality, and ethics}

It's frustrating because it appears superficially to be a financial campaign but it's fundamentally about climate justice (Friends of the Earth Scotland).

The interview data revealed that the underlying legitimating discourse for most divestment campaigners in Scotland was embedded in a morality frame. The key concern for campaigners was to place future health and welfare at the centre of the debate. Interviewees stated that because universities educate and research for the purposes of finding the 'truth', and churches operate around the core principles of justice and equity, then it is these institutions that should carry a primary moral duty to act on climate change.

Interviewees also used a frame of climate justice to draw attention to the ethical and political dimensions of climate change. They drew specific attention to the unequal distribution of environmental harms, highlighting that they cluster most significantly around economically and politically marginalised social groups or countries (Walker 2012; Adger 2001). A campaigner from Friends of the Earth Scotland relayed a story from Mozambique:

The financial gas project in Mozambique, led by Eni and ExxonMobil, is violating many human and environmental rights. Even though the drilling hasn't begun, hundreds of people are already being forcibly relocated from their homes. Fishing communities are being moved inland, farming communities are losing their fields and ultimately their livelihoods. $80 \%$ of people in Mozambique do not have access to electricity, the gas being drilled for here will not be used for their benefit. It will be processed and exported to other countries, in particular those in Europe.

In such instance, climate change is conceived in terms of a human catastrophe. It has stripped local populations of their resource and ability to take effective measures themselves. Nevertheless, climate justice was not only referred to in an international context. It was also often noted that the poorest communities in Scotland are suffering the most from air pollution. But it was also recognised that thousands of people, who rely upon the Scottish oil and gas industry for their employment, will be disproportionately affected by the transition towards a zero-carbon economy. Campaigners gave recognition to the rights of these workers and advocated for a 'just transition' that provides financial support.

While many campaigners employed a distributive justice frame, many interviewees referred to the need to divest for the sake of their own future and for the future of their pension. For example, a campaigner from Fossil Free Glasgow stated, 'This is a moral issue, an environmental issue and a whole future issue. Some will often use the phrase well there are no jobs on a dead planet, well there are no pensions on a dead planet either'. Conversely, connections were also made between pension funds being invested in an 'immoral' industry and the impact that industry is having on future generations:

I just think its abhorrent, repugnant, whatever you want to say, that my future is invested in depriving other people of their future. (Fossil Free Glasgow).

It's not right to be giving money to these companies that are harming our planet and threatening our survival, 
everybody's survival and generations to come. (Divest Scotland)

We need an urgent response at all levels, time has come for the Scottish parliament and government to begin ethical environmental investments for a sustainable future, for workers, communities, children and grandchildren. (Divest Scotland)

Such framings transform climate change into an explicitly moral issue, placing increased responsibility on governments to protect vulnerable communities and future generations.

\section{‘Climate emergency' and urgent action}

In October 2018, the Intergovernmental Panel on Climate Change reported that irreversible climate change will occur by 2030 unless global warming is kept below $1.5^{\circ}$ (IPCC 2018). Subsequently numerous countries have declared climate emergencies. Parts of the UK were the first to do so, in the devolved governments of Scotland and Wales. As a result, the notion of 'climate emergency' became pivotal in divestment campaigns. It was consistently used by all interviewees in preference to that of 'climate change'. There appeared to be widespread agreement that there is only a narrow window of opportunity to affect radical economic and social reform. The narrative of 'climate emergency' coalesced with those of 'the world is coming to an end', 'climate crisis', 'the planet is being destroyed' and 'I'm terrified by how much worse the situation is getting'. For example, a campaigner for Divest Lothian stated 'There has been a huge change in the terminology we now use. We've gone from climate change, to climate destruction. We don't use the term global warming, we now use global heating, because we are consciously doing it'. The transition to a more 'radical' terminology emphasises the need for urgent action and immediate transformative change. The frame of 'climate emergency' in particular focuses attention on the fundamental contradictions of continuing to support the fossil fuel industry in the context of a fragile climate.

\section{Theoretical and empirical links: from divestment frames to influencing government discourse and policy}

The main obstacle is those who have an obsession of holding on to old visions and what is often difficult is those people are often in great positions of power. It's how to tickle them to let go of that power (Divest Lothian).

A key premise of this article is to explore the power of discursive frames to motivate action and to assess the extent to which campaign groups can impact government discourse and policy. Influencing climate governance is of course rarely linear; it operates at many different levels and through many different channels. To explore this in some detail requires further analysis of the material and rhetorical tactics used by Scottish divestment movements to influence the policy pronouncements and positions of the Scottish government.

The key questions remain: how far can citizen mobilisation shape climate policy? And under what conditions?

\section{Awareness raising and changing social values}

The divestment movement in Scotland appears to roughly adopt a three-stage model of mobilisation as outlined by Bomberg (2012): awareness raising, alliance building, and network creation. Awareness raising includes not only engaging in effective communication and basic information dissemination, but also effectively communicating the importance and urgency of climate change to the public. As explored above, the notion of a 'climate emergency' has become pivotal within Scottish divestment campaigns. Instead of informing the public about climate 'facts', a more emotive language has been employed to encourage greater engagement and individual mobilisation. 'Framing an issue as catastrophically urgent is in part a campaign device meant to overcome institutional barriers to action by galvanising the public' (Bomberg (2012, p. 414). Similarly, Meyer (2003) has insisted that agenda setting outside of institutional politics is not simply self-referential but can significantly impact on the 'agenda within'.

\section{Building climate alliances}

Alliance building refers to forming connections with other likeminded actors in order to expand the scope and reach of a campaign. Meyer and Rochon (1997) and Piggot (2018) contend that social movements are typically comprised of an array of actors, who might share similar, but varying, goals, aims, and interests. Mobilisation around climate change is therefore rarely brought about by a single movement. Indeed, the Divest Scotland campaign built alliances with a range of divestment campaigns, targeting universities, churches, and local authorities as well as other pressure groups such as Extinction Rebellion and the youth climate strikers. This research substantiates the argument made by Bomberg (2012) that environmental campaigns must engage in building climate alliances in order to achieve their longerterm aim of influencing policy. Similarly, Piggot (2018) notes that it is often difficult to attribute policy influence to any one single actor or tactic. Indeed, what was made apparent from the interview data was that all divestment movements are deeply connected. Some referred to themselves as a 'little community'. Different groups have managed to establish a common set of values and a unified voice that, it is claimed, 
holds potential to challenge existing discourses and power structures: 'I think it's really great that these huge alliances have started to form, it's getting more people involved in the climate dialogue' (Divest Scotland).

In this way, the frames of divestment are also diffused into other movements and vice versa. An interviewee from the Church of Scotland, for example, argued that frame diffusion has created a more consistent and powerful rhetoric across different environmental campaigns: 'The television, the media, the Greta Thunbergs, the David Attenboroughs and the UN report of 1.5 has come together and everything just clicks now'.

Although pinpointing the exact location of mobilisation influence is challenging, alliance building also opens up new windows of opportunity. Alignment has enabled activists to move between and across different campaigns as and when it was deemed necessary:

If you've got a target and people keep completely ignoring you, temptation is to keep banging your head against a brick wall, but that's not a good idea. Sometimes people have managed to bang their head against a wall so hard that they have broken through but it doesn't normally work and leaves you feeling pretty injured. So move onto something else, find another target (Friends of the Earth Scotland).

You do need, in general, to have a bit of an eye on previous things, so when the opportunity comes, you come back to it. I think this spring with all the councils declaring climate emergencies, I think you can see people coming back onto council divestment (Divest Scotland).

How do we make change, we don't make it just by one thing, you have to operate and work at so many different levels to achieve change. You then have to identify enough correlation between these approaches so that at a certain point we achieve a social, political and economic tipping point (Divest Lothian).

The tactic of divestment is unique in targeting multiple institutions, at various levels. It has built a diverse network ranging from the small-scale local to largescale international campaigns. It has targeted local councils, churches, universities, arts institutions, and national governments. It reflects the view that if victories can be won at the local level, then broader national and international engagement becomes possible (McAdam 2017). This was confirmed by numerous interviewees:

It's like dominos, the more people who are talking about climate action and divestment the greater reaction we'll get (People and Planet Edinburgh).
I think this campaign of attrition, for steadily going for different targets for encouraging different institutions, all of this slowly allows a message to get out and then of course you reach a tipping point (Divest Lothian).

By networking and creating alliances with other climate groups, Divest Scotland has successfully transcended its own boundaries. While the divestment movement has its own unique targets, tactics, and aims, it provides a valuable platform for easing the public into climate awareness and activism. It bridges traditional lobbying and those actions deemed more radical. Nevertheless, the question remains of 'how do we get from alliance building to the transformative shift in policy direction mandated by climate change?' As Bomberg (2012, p. 418) concludes, 'some sort of agency is needed beyond alliances that can transcend levels, institutions, and interests and mobilise polities toward policy goals'.

\section{Mobilisation networks and lobbying government}

Tarrow (1998, p. 4) has defined social movements as 'collective challenges based on common purposes, in sustained interaction with elites, opponents and authorities'. As such if movements are to infiltrate and guide policy, campaigners must also engage with stakeholders who may not necessarily be 'natural allies'. Engaging with other stakeholders helps to extend the boundaries and reach of a movement's frames. This involves actors bargaining with stakeholders over the direction of climate policies. Bomberg (2012) refers to such processes as network creations.

The Divest Scotland campaign, in particular, was designed to directly connect MSPs to the climate problem by targeting their pension funds. The main aim of the campaign was to persuade MSPs to sign the pledge:

I pledge to support the Scottish Government and Parliament divesting from fossil fuels and investing in a just transition to a zero-carbon economy over an appropriate time scale.

Campaigners firstly conducted background research on individual MSPs to gain insights into the issues to which they appeared most sympathetic: 'When we try to approach an MSP we'll try and scroll through what they've previously said about climate change. So for example one MSP was very concerned about air pollution and so when we spoke to them we tried to tailor the conversation to that' (Divest Scotland). The strategy of convincing one MSP to sign the pledge (an early frame adopter) was designed to catalyse a wave of support. When an MSP signs the pledge, efforts are then made to spread the news via social media and encourage further support by thanking them publicly. When a critical mass of MSPs has signed and accepts the frames of divestment, it is expected 
that other MSPs will follow (Green 2018). This frame diffusion is designed to shame those MSPs who refuse to do so. 'It's a norming and storming thing, like oh if they all think it's safe it must be, so I'll support it too' (Divest Lothian).

While lobbying an MSP is an example of direct targeting and campaigning, the influence and power these interactions can have are more subtle. It depends upon campaigners carefully selecting those frames they deem most likely to influence and persuade MSPs. Certain frames will align more strongly with MSP's previous convictions. Here, Ruzza (2002, p. 101) draws upon the concept of frame bridging; 'By frame bridging we refer to the linkage of two or more ideologically congruent but structurally unconnected frames regarding a particular issue or problem.' A frame bridge is often a compromise between social movement discourse and institutional discourse. Movement influence is therefore more likely to be reflected in a dilution (rather than wholesale rejection) of existing policies.

Mobilisation networks may or may not shape policy in the short term, but what makes them distinctive is the power to shift norms, practices, and principles underlying climate politics and economics over time. Their impact may be greater in redefining political agendas from the outside; in laying the seeds for a long-term strategy to 'reframe the issues, shift norms, realign economic incentives and craft new rules' (Levy 2011, p. 488). Even if a mobilisation effort ultimately fails to influence a given policy, the movement may still play a role in shaping future decisions. For example, a movement may win concessions for involvement in policy-making processes (Olzak and Soule 2009); create resources such as social networks and organisational infrastructure that enable future movements to achieve success (Diani and McAdam 2003); or shift the political discourse, so that moderate alternatives to the policies advanced by the movement gain traction (Schifeling and Hoffman 2017).

\section{Governmental discourse: from 'climate change' to 'climate emergency'?}

This study of campaigner divestment frames, frame alignments, and frame bridging draws attention to the role of particular schema and discourses in the formulation (diagnostic framing) and promotion (prognostic framing) of particular policies. But to have influence campaigns require support from powerful actors in influential venues. Ideas can swim around in a 'policy soup', but until they are taken up in appropriate ways they lack authority and do not compel actions or attract direct resources. As made clear by Corell and Betsill (2008), it is difficult to trace any precise impact campaigner discourse and action may have on governmental policy and practice. Nevertheless, it remains possible to explore how far the various collective action frames of divestment have come to be reflected in recent shifts in the climate change policy terrain of the Scottish government.

\section{Financial risk and economics}

During the decade 2009-2019, economic impacts remained a central component of the Scottish government's climate change conversation. Despite this, there has been a shift in emphasis away from purely economic considerations and motivations and towards acknowledgement of wider environmental issues. For example, in 2011, the economy was the main motive for government to take climate action. For instance, it stated, 'This government's purpose is to focus government and public services on creating a more successful country, with opportunities for all of Scotland to flourish, through increasing sustainable economic growth' (Scottish Government 2011, p. 4). A low-carbon economy was therefore only given precedence due to its potential to allow Scotland to become a key competitor in the world economy. It was also hoped that 'greening up' would lead Scotland out of the 2008 recession. By 2019, however, the government was now claiming 'we will place climate change at the heart of everything we do' (Scottish Parliament 2019, p. 6). It appeared that the primary audience of the Scottish government's climate change policy had shifted away from energy companies and towards environmentalists.

Furthermore, less pessimism now appears to surround the transition towards a low-carbon economy. In 2009, the Climate Change (Scotland) Act was concerned with the negative impact emission reduction targets would have on the Scottish economy and its competitiveness, as well as job and employment opportunities. Since then, there has been a notable shift in terminology. Not only does the Scottish Government now refer to a zero-carbon or carbon-neutral economy, but also uses more 'positive' terms such as 'potential', 'innovation', 'revolutionise', 'economic benefits', and 'advantageous position' (Scottish Government 2018a; Scottish Government 2019a). Nevertheless, it also perseveres with a contrary frame of 'sustainable economic growth'. A Divest Scotland campaigner highlighted this problem when discussing the role of the Scottish National Investment Bank: "There is no criticism of the term "sustainable economic growth" in the Bank's aims, when the term has been roundly criticized and is usually interpreted to mean "infinite economic growth". This underlines a key concern of campaigners that the continuance of an economic frame enables governments to fall back on policies that simply promote market mechanisms and 'business as usual'.

\section{Climate justice, morality, and ethics}

Scotland's climate change policies have referenced moral obligations since 2011. However, their reasoning and 
justification have changed. In 2011, morality was referred to in the sense that Scotland has a duty to share its specialist knowledge with 'underdeveloped' countries. The following statement from 2011 appears to have neocolonial undertones:

We also have a moral obligation as an industrialised country to act on climate change and influence others worldwide to do the same. Many countries are less fortunate than Scotland, and do not share our wealth of natural resources and renewable energy potential. We are, in the business of sharing knowledge and information, creating partnerships between academic institutions, and working with countries who are likely to be disproportionately affected by climate change, such as the Maldives (Scottish Government 2011, p. 12).

Such a statement fails to acknowledge Scotland's duty to act on climate change due to its industrial past and reliance on carbon-intensive industries, but instead places Scotland on a moral high ground that has a duty to share its 'elitist' knowledge and encourage others to act. Significantly no mention is given to providing financial support to countries in the Global South who are disproportionally impacted by climate change due to the UK's imperial and colonial history.

Similarly, in 2013, the government argued: 'Addressing climate change is not solely an environmental and moral imperative, it is also a massive economic opportunity for Scotland' (Scottish Government 2013, p. 27). Yet 5 years later, the government was stating 'We have a moral responsibility to do what we can to tackle the effects of climate change, particularly as they will be felt most strongly by those vulnerable communities who have done the least to cause it' (Scottish Government 2018a, n.p.). There now appeared some recognition that the decisions and actions made in Scotland affect vulnerable societies and environments within and outside Scottish borders (Scottish Government 2019b). For example, the Climate Change (Scotland) Bill 2019 advocates the provision of impact assessments for each policy and proposal on island communities, migrants, and people in vulnerable situations. Above all, there now appeared to be an acceptance that the government has a 'moral responsibility to tackle climate change for those yet to be born' and a requirement 'to safeguard the planet for future generations' (Scottish Government 2018b, p. 9; Scottish Government 2019c, n.p).

\section{'Climate emergency' and urgent action}

There appears to be two pivotal moments in the Scottish government climate change policy. Prior to 2009, the government was referring to the oil and gas industry as an essential institution that will help drive the transition towards a low-carbon economy. But by 2013, the first tipping point arrived. The government began referring to climate change as a 'catastrophe' and the 'greatest threat we face' (Scottish Government 2013, p. 27, p. 1). It was now presented as a necessity to tackle climate change, rather than an option. By 2018/2019, a second tipping point occurred. The frame of urgent action became more prominent. The government was now referring to the need for transformational change, cultural shifts, and a change in social norms (Scottish Government 2019a). The government's Big Climate Conversation report from Roseanna Cunningham MSP, Cabinet Secretary for Environment, Climate Change and Land Reform, also reflected a shift in discourse from that of 'climate change', towards that of 'climate emergency'. She stated: 'There is a global climate emergency. The evidence is irrefutable. The science is clear, and people have been clear: they expect action' (Scottish Government 2019d, n.p.).

Another important change in governmental policy was its response to adaptation. In 2014, the Climate Ready Scotland: Scottish Climate Change Adaptation Programme demonstrated the government's reliance on adaptation strategies: 'preparing effectively for unavoidable climate change is an essential action' and 'it is important that Scotland is well prepared and resilient to change' (Scottish Government 2014, p. 1). Little mention was given to mitigation efforts. However, the new climate change adaptation programme (Scottish Government 2019a) advocates a greater combination of mitigation and adaptation strategies. For the first time, Scotland's adaptation programme will explore the actions individuals can take in their everyday lives to reduce their environmental impact (Scottish Government 2019a). In addition, in 2019, when referring to climate actions, mention was given to closing down power stations and abandoning carbon offsetting. This demonstrates something of a shift towards more 'radical' action. It reflects Schiefling and Hoffman's (2017) argument that when campaigns (such as divestment) advocate 'extreme', 'radical flank' positions, other more liberal ideas may come to be seen as legitimate and reasonable.

Despite this evidence of some convergence between campaigner and governmental discourses, interviewees continued to note key contradictions in the government's position:

Some institutions can be so hypocritical. They claim to be taking action on climate change and publish all these shiny documents saying "look at all the great things we're doing, we're installing solar panels here and we're promoting active travel" but at the same time they have $\mathrm{x}$ millions actually invested in the same companies driving the problem. (Divest Lothian).

In particular, since the Scottish government's declaration of a 'climate emergency', campaigners have become more 
aware of the discrepancy between governmental rhetoric and practice:

How can the government contemplate increasing air traffic while saying there is a climate emergency? (Church of Scotland).

Representatives go on about having the best climate change legislation in the world but next week they're celebrating that we've opened another oil field in Scotland (Divest Lothian).

\section{Concluding discussion}

The signing of the 1997 Kyoto Protocol, designed to reduce greenhouse gas emissions, was considered to mark a significant step forward due to its novel institutional procedures and ambitious emission reduction targets (Andresen and Agrawala 2002). Two decades later, the Paris Agreement of 2016 requested all countries to develop Nationally Determined Contributions (NDCs) for climate change mitigation. However, such measures are persuasive rather than legally binding. As a result, there remains considerable concern that governments are simply failing to translate aspirations into firm commitments. The extent of international compliance is in particular marked by persistent American non-participation (Pickering et al. 2018).

As a result, Ayling and Gunningham (2017, p. 132) argue that this void has been filled by local and transnational activist networks, such as divestment, which have increasingly come to constitute the "leading edge of this wave of non-state mitigation initiatives'. Similarly, Jagers and Stripple (2003) have advocated forms of climate governance which give greater consideration to the power of small-scale, grassroots actors. Some feminist perspectives also call for greater attention to be given to the fluid, everyday, and unorganised forms of power that can play a part in constructing and determining policy (Agarwal 2010). In particular, Ayling and Gunningham (2017) now consider that forms of non-state governance, such as divestment, have come to play a vital role, as 'norm entrepreneurs' and 'policy shapers', in shifting the terms of political and environmental discourse.

However, as Mangat et al. (2018, p. 188) conclude, 'systematic analysis of the movement by social scientists is still in its infancy'. They explored the politics of divestment, as expressed in campaign literature and media sources, and found it to rest on four overlapping narratives of war and enemies, morality, economics, and justice. For them the war/ enemy narrative was prominent. In contrast, the current research, based on face-to-face interviews with campaigners in Scotland, found a rather less confrontational but uneasy swirl of motives oscillating between morality and markets. As such the collective action frames of campaigners lack a certain consistency. The simultaneous mobilisation around frames of climate justice (morality) and finance (markets) presents a significant challenge. On the one hand, a frame of climate justice demonstrates divestment's commitment to more radical aspirations and a holistic approach to tackling climate change, while on the other hand, a finance frame perpetuates notions of ecological modernisation and market solutions.

Significantly too, while this research may have revealed some notable shifts in Scottish government's climate change rhetoric and policy, economic frames have remained prominent. Governmental discourse has never embraced the tactic of divestment itself and has no mention of removing investments from fossil fuel industries. While superficially there appears to be a convergence between some campaign frames and governmental discourse, there remains significant disjuncture between rhetoric and practice. Clearly further research is required to examine the longer-term influence the Divest Scotland campaign may have on governmental statements, practices, and policies. However, what can be drawn from this research is that divestment campaigns play an important role in discursive work. Divestment alone may not be able to deliver the wide-scale policy changes needed to create a fossil-free future, but it can play a key role in inspiring the public to collectively reimagine themselves, their future, and the role they can play in ensuring that the future is indeed 'fossil-free'.

Data availability N/A

\section{Compliance with ethical standards}

Conflict of interest The author declares that there are no conflicts of interest.

Code availability N/A

Open Access This article is licensed under a Creative Commons Attribution 4.0 International License, which permits use, sharing, adaptation, distribution and reproduction in any medium or format, as long as you give appropriate credit to the original author(s) and the source, provide a link to the Creative Commons licence, and indicate if changes were made. The images or other third party material in this article are included in the article's Creative Commons licence, unless indicated otherwise in a credit line to the material. If material is not included in the article's Creative Commons licence and your intended use is not permitted by statutory regulation or exceeds the permitted use, you will need to obtain permission directly from the copyright holder. To view a copy of this licence, visit http://creativecommons.org/licenses/by/4.0/.

\section{References}

Adger N (2001) Scales of governance and environmental justice for adaptation and mitigation of climate change. J Int Dev 13(7):921-993 
Agarwal, B. (2010) Gender and Green Governance: The political Economy of Women's Presence; Within and Beyond Community Forestry. Oxford: Oxford University Press.

Andresen S, Agrawala S (2002) Leaders, pushers and laggards in the making of the climate regime. Glob Environ Chang 12(1):41-51

Ayling J, Gunningham N (2017) Non-state governance and climate policy: the fossil fuel divestment movement. Clim Pol 17(2):131-149

Benford R, Snow D (2000) Framing processes and social movements: an overview and assessment. Annu Rev Sociol 26(1):611-639

Bomberg E (2012) Mind the (mobilization) gap: comparing climate activism in the United States and European Union. Rev Policy Res 29(3):408-430

Bratman E, Brunette K, Shelly D, Nicholson S (2016) Justice is the goal: divestment as climate change resistance. J Environ Stud Sci 6(4): 677-690

Cleveland C and Reibstein R (2015) The path to fossil fuel divestment for universities: climate responsible investment. Boston University, Department of Earth and Environment.

Corell E, Betsill M (2008) Analytical framework: assessing the Influence of NGO Diplomats. In: Betsill M, Corell E (eds) NGO Diplomacy: the influence of NGOs in international environmental negotiations. MIT Press, Massachusetts, pp 19-42

Curnow J, Gross A (2016) Injustice is not an investment: student activism, climate justice and the fossil fuel divestment campaign. In: Conner J, Rosen S (eds) Contemporary youth activism: advancing social justice in the United States. Praeger, California, pp 367-383

Diani M, McAdam D (eds) (2003) Social movements and networks: relational approaches to collective action. Oxford University Press, Oxford

Grady-Benson J (2014) 'Fossil fuel divestment: the power and promise of a student movement for climate justice'. Available at: https:// scholarship.claremont.edu/pitzer_theses/55/ (Accessed 28 November 2019).

Green F (2018) Anti-fossil fuel norms. Climate Change 150(1-2):103116

Gunningham N (2017) Review essay: divestment, non-state governance, and climate change. Law Policy 39(4):309-324

Healy N, Bary J (2017) Politicizing energy justice and energy system transitions: fossil fuel divestment and a just transition. Energy Policy 108(1):451-459

Healy N, Debski J (2017) Fossil fuel divestment: implications for the future of sustainability discourse and action within higher education. Local Environ 22(6):699-724

IPCC (2018) Global warming of $1.5^{\circ} \mathrm{C}$. IPCC, Switzerland

Jagers S, Stripple J (2003) Climate governance beyond the state. Glob Gov 9(3):385-399

Klein N (2014) This changes everything. Simon and Schuster, New York

Levy D (2011) Private sector governance for a sustainable economy: a strategic approach. Rev Policy Res 28(5):487-493

Mangat R, Dalby S, Paterson M (2018) Divestment discourse: war, justice, morality and money. Env Polit 27(2):187-208

McAdam D (2017) Social movement theory and the prospects for climate change activism in the United States. Annu Rev Polit Sci 20(1):189 208

McKibben B (2012) 'Global warming's terrifying new math', Rolling Stone, 19 July. Available at: https://www.rollingstone.com/ politics/politics-news/global-warmings-terrifying-new-math188550/ (Accessed 28 November 2019).

McKibben B (2018) 'At last, divestment is hitting the fossil fuel industry where it hurts', The Guardian, 16 December. Available at: https:// www.theguardian.com/commentisfree/2018/dec/16/divestmentfossil-fuel-industry-trillions-dollars-investments-carbon (Accessed 28 November 2019).

Moore J (2011) Ecology, capital and the nature of our times: accumulation and crisis in the capitalist world ecology. American Sociological Association 17(1):107-146
Meyer D (2003) Social movements and public policy: eggs, chicken, and theory, University of California, Irvine: Center for the Study of Democracy. Available at: https://escholarship.org/uc/item/ 2m62b74d (Accessed 29 September 2020).

Meyer D and Rochon T (1997) 'Toward a coalitional theory of social and political movements.' In: T. Rochon and D. Meyer (eds). Coalitions and political movements: the lessons of the nuclear freeze. Boulder: Lynne Rienner. 237-252.

Olzak S, Soule S (2009) Cross-cutting influences of environmental protest and legislation. Social Forces 88(1):201-225

Pan Z, Kosicki G (1993) Framing analysis: an approach to news discourse. Polit Commun 10(1):59-79

Pickering J, McGee J, Stephens T, Karlsson-Vinkhuyzen S (2018) The impact of the US retreat from the Paris Agreement: Kyoto revisited? Clim Pol 18(7):818-827

Piggot G (2018) The influence of social movements on policies that constrain fossil fuel supply. Clim Pol 18(7):942-954

Rowe J, Dempsey J, Gibbs P (2016) The power of fossil fuel divestment (and its secret). In: Carroll W, Sarker K (eds) A world to win: contemporary social movements and counter hegemony. ARP Books, Manitoba, pp 233-249

Ruzza C (2002) 'Frame bridging' and the new politics of persuasion, advocacy and influence'. In: A. Warleigh and J. Fairbrass (eds.). Influence and interests in the European Union: the new politics of persuasion and advocacy. London: Europa Publications, Taylor and Francis. 93-117.

Schifeling T, Hoffman A (2017) Bill McKibben's Influence on U.S. Climate change discourse: shifting field-level debates through radical flank effects. Organ Environ 32(3):213-233

Scottish Government (2011) Low carbon Scotland: meeting the emissions reduction targets 2010-2022. The Report on Proposals and Policies. Edinburgh: Scottish Government.

Scottish Government. (2013) Low carbon Scotland: meeting the emissions reduction targets 2013-2027. The Second Report on Proposals and Policies. Edinburgh: Scottish Government.

Scottish Government (2014) Climate ready Scotland: Scottish climate change adaptation programme. Scottish Government, Edinburgh

Scottish Government (2018a) 'Tackling climate change', Scottish Government, 5 October. Available at: https://www.gov.scot/news/ tackling-climate-change-6/ (Accessed 1 February 2020).

Scottish Government (2018b) Climate change plan. The Third Report on Proposals and Policies 2018-2032. Scottish Government, Edinburgh

Scottish Government (2019a) Climate ready Scotland: Scottish climate change adaptation programme 2014. Fifth Annual Progress Report. Edinburgh: Scottish Government.

Scottish Government (2019b) Just transition commission background report. Scottish Government, Edinburgh

Scottish Government (2019c) 'Climate change action', Scottish Government, 2 May. Available at: https://www.gov.scot/news/ climate-change-action-1/ (Accessed 1 February 2020).

Scottish Government (2019d) 'The big climate conversation: global climate change emergency'. Available at: https://www. theyworkforyou.com/sp/?id=2019-05-14.4.0 (Accessed 1 February 2020).

Scottish Parliament (2019) Stage 2 Report on the Climate Change (Emissions Reduction Targets) (Scotland) Bill. Scottish Parliamentary Corporate Body, Scotland

Scottish Government (2020) 'Climate change' Available at: https://www. gov.scot/policies/climate-change/ (Accessed 21 February 2020).

Tarrow S (1998) Power in movement: social movements and contentious politics, $2^{\text {nd }}$ Edition. Cambridge: Cambridge University Press.

Walker G (2012) Environmental justice: concepts, evidence and politics. London: Routledge. 
